\title{
High-Active Metallic-Activated Carbon Catalysts for Selective Hydrogenation
}

\author{
Nicolás Carrara $\mathbb{D}^{1},{ }^{1}$ Carolina Betti, ${ }^{1}$ Fernando Coloma-Pascual, ${ }^{2}$ María Cristina Almansa $\mathbb{D D}^{2}$ \\ Laura Gutierrez, ${ }^{1,3}$ Cristian Miranda, ${ }^{4}$ Mónica E. Quiroga $\mathbb{D}^{1,3}$ and Cecilia R. Lederhos ${ }^{10}{ }^{1}$ \\ ${ }^{1}$ Instituto de Investigaciones en Catálisis y Petroquímica (INCAPE) (FIQ-UNL, CONICET), Colectora Ruta Nac., No. 168 Km 0, \\ Pje El Pozo, 3000 Santa Fe, Argentina \\ ${ }^{2}$ Servicios Técnicos de Investigación, Facultad de Ciencias, Universidad de Alicante, Apartado 99, 03080 Alicante, Spain \\ ${ }^{3}$ Facultad de Ingeniería Química, Universidad Nacional del Litoral, Santiago del Estero 2654, 3000 Santa Fe, Argentina \\ ${ }^{4}$ Laboratorio de Investigación en Catálisis y Procesos (LICAP), Universidad del Valle, Ciudad Universitaria Meléndez, \\ Calle 13 \# 100-00, Cali, Colombia
}

Correspondence should be addressed to Cecilia R. Lederhos; clederhos@fiq.unl.edu.ar

Received 30 January 2018; Revised 23 April 2018; Accepted 30 April 2018; Published 5 July 2018

Academic Editor: Raghunath V. Chaudhari

Copyright (c) 2018 Nicolás Carrara et al. This is an open access article distributed under the Creative Commons Attribution License, which permits unrestricted use, distribution, and reproduction in any medium, provided the original work is properly cited.

\begin{abstract}
A series of low-loaded metallic-activated carbon catalysts were evaluated during the selective hydrogenation of a medium-chain alkyne under mild conditions. The catalysts and support were characterized by ICP, hydrogen chemisorption, Raman spectroscopy, temperature-programmed desorption (TPD), temperature-programmed reduction (TPR), X-ray diffraction (XRD), Fourier transform infrared spectroscopy (FTIR micro-ATR), transmission electronic microscopy (TEM), and X-ray photoelectronic spectroscopy (XPS). When studying the effect of the metallic phase, the catalysts were active and selective to the alkene synthesis. $\mathrm{NiCl} / \mathrm{C}$ was the most active and selective catalytic system. Besides, when the precursor salt was evaluated, PdN/C was more active and selective than $\mathrm{PdCl} / \mathrm{C}$. Meanwhile, alkyne is present in the reaction media, and geometrical and electronic effects favor alkene desorption and so avoid their overhydrogenation to the alkane. Under mild conditions, nickel catalysts are considerably more active and selective than the Lindlar catalyst.
\end{abstract}

\section{Introduction}

Olefins are of great academic and industrial interest. They are very important raw material for the synthesis of biologically active compounds, margarine, and lubricants, as well as in plastic industry [1]. Also, olefins present many applications in fine chemistry. The purification of olefins is a very important step in manufacturing polymers with a $0.35 \%$ content of impurities, as alkyne compounds, leading to a polymer with undesirable properties. There are several ways of purification of olefins stream, and the most common is solvent extraction, which is a nonecological friendly procedure. Another alternative for obtaining olefins is via the selective hydrogenation of alkynes. This catalytic process is the major challenge because they reduce the production costs and let obtaining good yields and high selectivities.
Different noble metals as $\mathrm{Pd}, \mathrm{Pt}, \mathrm{Ru}$, and $\mathrm{Rh}$ anchored on inorganic supports are highly active and selective for carboncarbon multiple bond hydrogenations [2-7]. During the partial hydrogenation of alkynes to alkenes, or dienes to olefins, many authors found that supported palladium catalysts presented the highest catalytic activities $[8,9]$. The most used catalyst for alkyne partial hydrogenation is the commercial Lindlar catalyst, that contains palladium poisoned with lead $\left(\mathrm{Pd} / \mathrm{CaCO}_{3}, 5\right.$ wt.\% $\mathrm{Pd}$ modified with $\mathrm{Pb}$ $\left.(\mathrm{OAc})_{2}\right)^{2}[10]$. The cost of this noble metal has increased greatly in the last decade, and the world tendency is to develop cheaper catalysts by lowering the Pd content or by using cheaper metals.

In previous papers $[11,12]$, we have studied the partial hydrogenation reaction of a medium-chain alkyne (1-heptyne) to obtain the corresponding olefin using monometallic 
catalysts using alumina and carbonaceous supports. In these papers, the influences of different supports, reaction, and reduction temperature and the metallic phase on the activity and the selectivity were evaluated.

Activated carbonaceous surfaces have been studied during the last decades $[13,14]$ in different reactions showing that they are very complex. Carbonaceous supports are widely used because of their inertness, stability, high specific surface, low cost, and ability to easily recover the metallic phase after ending their useful life. Besides, during the synthesis of the catalysts, on the surface of activated carbon, different oxygenated and nitrogenized functional groups are found, and both can be easily modified when the material is physically or chemically pretreated $[15,16]$.

The objectives of this work were to synthesize low-loaded $\mathrm{Ru}, \mathrm{Pd}$, and Ni catalysts using an activated carbon as support and evaluate their activities and selectivities during 1-heptyne selective hydrogenation reaction under mild conditions. The effect of the type of metal and the precursor salt on the activity and selectivity to the desired product (1-heptene) is also evaluated. The Lindlar catalyst was used as a reference.

\section{Experimental}

2.1. Catalyst Preparation. CNR-115 pelletized activated carbon provided by NORIT $\left(S_{\mathrm{BET}}\right.$ : $1503 \mathrm{~m}^{2} \cdot \mathrm{g}^{-1}$, micropore volume: $0.738 \mathrm{~mL} \cdot \mathrm{g}^{-1}$, and total pore volume: $1.010 \mathrm{~mL} \cdot \mathrm{g}^{-1}$ ) was used as a support. Chloride acidic solutions of $\mathrm{Ru}, \mathrm{Pd}$, and $\mathrm{Ni}$ (purity $>99.98 \%$ ) at $\mathrm{pH}=1$ with $\mathrm{HCl}$ were used to prepare $\mathrm{PdCl} / \mathrm{C}, \mathrm{RuCl} / \mathrm{C}$, and $\mathrm{NiCl} / \mathrm{C}$ catalysts by the incipient wetness technique. On the contrary, $\mathrm{PdN} / \mathrm{C}$ was prepared from $\mathrm{Pd}\left(\mathrm{NO}_{3}\right)_{2}$ acidic solution (purity $>99.98 \%$ ) at $\mathrm{pH}=1$ with $\mathrm{HNO}_{3}$. Solutions have the necessary concentration to obtain 0.4 wt.\% of each metal (M: Pd, Ni, and Ru) on the final catalyst. After impregnation, all samples were dried overnight at $373 \mathrm{~K}$ and reduced under a hydrogen stream, flow rate of $25 \mathrm{~mL} \cdot \mathrm{min}^{-1}$, at $393 \mathrm{~K}$ for $1 \mathrm{~h}$ before each catalytic evaluation.

2.2. Catalyst Characterization. Metal loadings of the catalysts were obtained by the ICP technique in PerkinElmer Optima 2100DV equipment, previous digesting the samples in a Start D Microwave Digestion system (Milestone).

Dispersion values were obtained by hydrogen chemisorption in Micromeritics Accusorb 2100e equipment after reducing each sample at $393 \mathrm{~K}$ for $1 \mathrm{~h}$ under $5 \% \mathrm{v} / \mathrm{v} \mathrm{H}_{2} / \mathrm{Ar}$, and an atomic ratio $\mathrm{H}: \mathrm{M}$ equal to 1 was assumed for all of the calculations as suggested by the other authors [17-19]. The particle diameter of the catalysts was calculated from the chemisorption results following the procedure reported by Paryjczac et al. [20, 21]. The adopted metallic surface area, $\sigma$ value, was calculated from the average of the densities of the (100), (110), and (111) crystal planes $[22,23]$; the values for $\mathrm{Pd}, \mathrm{Ru}$, and $\mathrm{Ni}$ were $1.27 \cdot 10^{19}$, $1.63 \cdot 10^{19}$, and $1.54 \cdot 10^{19}$ atoms $\cdot \mathrm{m}^{-2}$, respectively.

Temperature-programmed desorption (TPD) allowed to determine the amount and type of oxygen-containing groups on the activated carbon surface. $10 \mathrm{mg}$ of the sample were treated in a He stream at $100 \mathrm{~mL} \cdot \mathrm{min}^{-1}$ from 293 to
$1273 \mathrm{~K}$ at $20 \mathrm{~K} \cdot \mathrm{min}^{-1}$. In the experiments, the effect of the thrust is corrected using a "white" curve. $\mathrm{CO}$ and $\mathrm{CO}_{2}$ desorptions were measured in a simultaneous TG-DTA (Mettler Toledo model TGA/SDTA851e/LF/1600) coupled to a quadrupole mass spectrometer (Pfeiffer Vacuum model Thermostar GSD301T).

The FTIR micro-ATR technique was carried in a Shimadzu FTIR-8400 spectrophotometer which is based on the internal reflectance phenomenon. The FTIR micro-ATR technique is the most sensitive technique for surface analysis [24].

The Raman spectra were recorded using a LabRam spectrometer (Horiba-Jobin-Yvon) coupled to an Olympus confocal microscope (a 100x objective lens was used for simultaneous illumination and collection) and equipped with a CCD detector cooled to about $200 \mathrm{~K}$ using the Peltier effect. The excitation wavelength was $532 \mathrm{~nm}$ in all cases (Spectra-Physics diode pump solid state laser). The laser power was set at $30 \mathrm{~mW}$.

X-ray diffraction (XRD) measurements of powdered samples were obtained using a Shimadzu XD-D1 instrument with $\mathrm{CuK}_{\alpha}$ radiation $(\lambda=1.5405 \AA)$ in the $21<2 \theta<49^{\circ}$ at $0.25^{\circ} \cdot \mathrm{min}^{-1}$ scan speed.

The electronic state of superficial species and their atomic ratios were determined by X-ray photoelectron spectroscopy (XPS), following $\mathrm{Pd}$ and $\mathrm{Ru} 3 \mathrm{~d}_{5 / 2}, \mathrm{Ni}$ and $\mathrm{Cl}$ $2 \mathrm{p}_{3 / 2}, \mathrm{~N}, \mathrm{C}$, and $\mathrm{O} 1 \mathrm{~s}$ peaks' binding energy (BE) for catalysts and support. Measurements were acquired in VG-Microtech Multilab equipment, with $\mathrm{MgK}_{\alpha}(h v: 1253.6 \mathrm{eV})$ radiation and a pass energy of $50 \mathrm{eV}$. The analysis pressure during data acquisition was kept at $5.10^{-7} \mathrm{~Pa}$. Samples were treated in situ in the presence of a $\mathrm{H}_{2}$ stream following the same pretreatment conditions for each catalyst. A careful deconvolution of the spectra was made, and the areas of the peaks were estimated by calculating the integral of each peak after subtracting a Shirley background and fitting the experimental peak to a combination of Lorentzian/Gaussian lines of 30-70\% proportions. The reference binding energy (BE) was $\mathrm{C} 1 \mathrm{~s}$ peak at $285.0 \mathrm{eV}$. Determinations of the superficial atomic ratios were made by comparing the areas under the peaks after background subtraction and corrections due to differences in escape depth and in photoionization cross sections [25].

The reducibility of the surface species in all the catalysts was determined by temperature-programmed reduction (TPR) which was carried out in an Ohkura TP $2002 \mathrm{~S}$ instrument equipped with a thermal conductivity detector. Samples were pretreated at $373 \mathrm{~K}$ for $30 \mathrm{~min}$ under an argon stream, cooled up to room temperature under an argon flow, and then, the temperature was increased up to $1223 \mathrm{~K}$ at $10 \mathrm{~K} \cdot \mathrm{min}^{-1}$ in a $5 \%$ hydrogen/argon mixture stream.

Transmission electronic microscopy (TEM) photographs were obtained using an electronic microscope JEOL JEM-2011 at $200 \mathrm{kV}$. The samples were reduced for $1 \mathrm{~h}$ at $393 \mathrm{~K}$ and dispersed in distilled water in order to obtain TEM images which are only used for comparative purposes.

2.3. Catalytic Evaluation. The reaction test accessed was 1heptyne selective hydrogenation, carried out at $303 \mathrm{~K}$, $150 \mathrm{kPa}$, and $800 \mathrm{rpm}$ during $180 \mathrm{~min}$. The possibility of 


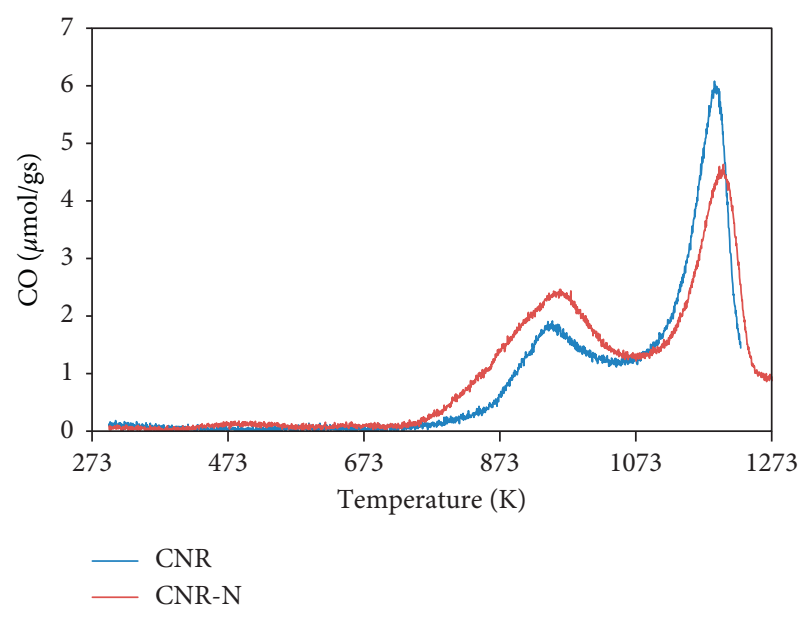

(a)

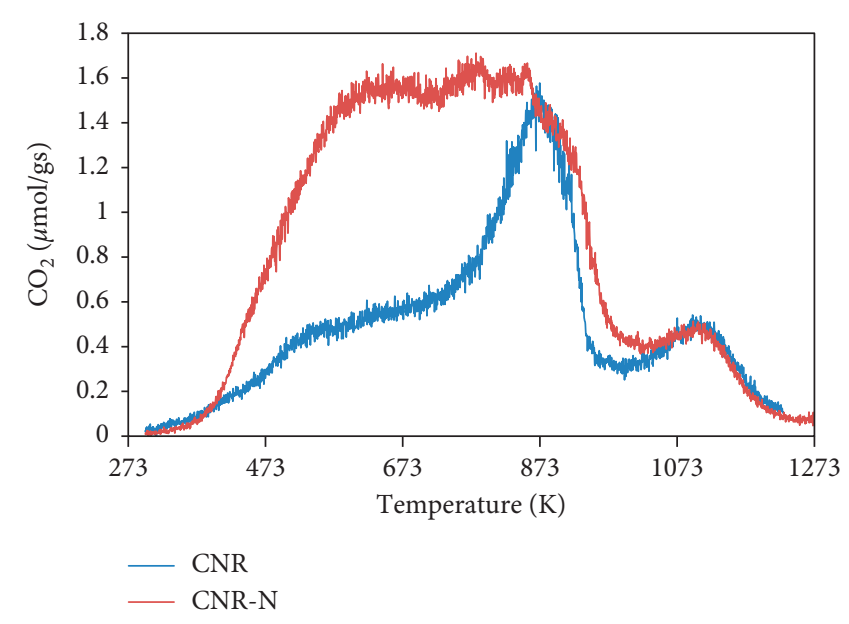

(b)

Figure 1: TPD spectra: (a) $\mathrm{CO}$ and (b) $\mathrm{CO}_{2}$ desorption profiles as a function of temperature for CNR and CNR-N samples.

external and internal diffusional limitations during the catalytic tests was discarded using a previously described procedure [26]. Experiments were performed in a stainless steel stirred tank reactor equipped with a magnetically driven stirrer with two blades in counterrotation. The inner wall of the reactor was completely coated with PTFE in order to neglect the catalytic action of the steel of the reactor found by other authors [27]. Samples of $0.75 \mathrm{~g}$ of the catalyst were used in a total volume of $75 \mathrm{~mL}$ of $5 \%(\mathrm{v} / \mathrm{v})$ solution of 1 heptyne (Fluka, Cat. no. 51950) in toluene (Merck, Cat. no. TX0735-44).

Blank tests were obtained using CNR and CNR-N activated carbons, and no conversion of 1-heptyne was observed. The commercial Lindlar catalyst (Aldrich Cat. no. 20,573-7) was used as a reference, maintaining constant S : M (1-heptyne/metal molar ratio). Reactant and products were analyzed by gas chromatography using a flame ionization detector and a HP INNOWax polyethyleneglycol capillary column.

\section{Results and Discussion}

3.1. Catalysts and Support Characterization. A way to know the number and nature of oxygen functional groups present on the carbon surface is by the temperature-programmed desorption (TPD) technique. It is well known $[15,16]$ that the treatment of the catalysts with a strong oxidant acid, such as nitric acid, modifies the oxygen amount and the kind of superficial groups in the carbon surface. For this purpose, a sample of the carbon support (CNR) was treated with $\mathrm{HNO}_{3}$ (CNR-N), and both were analyzed and compared by TPD. This allows studying the effect of nitric acid, which was used during the catalyst preparation step, on the CNR surface.

In Figures 1(a) and 1(b), the concentration profiles of $\mathrm{CO}$ and $\mathrm{CO}_{2}$ as a function of temperature, respectively, for CNR and CNR-N samples are shown. During the TPD experiments, the samples analyzed showed highly different behaviors, mainly during the $\mathrm{CO}_{2}$ desorption (Figure 1(b)) due to the decomposition of carboxyl and lactone groups. It
TABLE 1: Quantitative results of the TPD-MS analysis for carbon samples.

\begin{tabular}{lccc}
\hline & $\mathrm{CO}(\mu \mathrm{mol} / \mathrm{g})$ & $\mathrm{CO}_{2}(\mu \mathrm{mol} / \mathrm{g})$ & $\mathrm{O}(\mu \mathrm{mol} / \mathrm{g})$ \\
\hline $\mathrm{CNR}$ & 2349 & 1394 & 5136 \\
$\mathrm{CNR}-\mathrm{N}$ & 2621 & 2442 & 7504 \\
\hline
\end{tabular}

can be seen that these surface groups had highly increased in the carbon sample treated with the oxidizing acid $\left(\mathrm{HNO}_{3}\right)$.

The quantitative results from TPD-MS analysis for the CNR and CNR-N supports are presented in Table 1. The amount of surface oxygen groups of carbonaceous supports, estimated by $\mathrm{CO}, \mathrm{CO}_{2}$, and $\mathrm{O}_{2}$ evolved in TPD experiments (Table 1), shows that the oxidizing treatment with $\mathrm{HNO}_{3}$ produces a large amount of surface oxygenated complexes, with $175 \%$ higher amount of carboxylic-type groups that decompose to give $\mathrm{CO}_{2}$ under the heat treatment [28]. This enhancement is also observed in the TPD profile in Figure 1(b).

The FTIR micro-ART spectra are given in Figure 2(a) for the supports CNR and CNR-N and in Figure 2(b), for the catalysts $\mathrm{PdCl} / \mathrm{C}, \mathrm{PdN} / \mathrm{C}, \mathrm{NiCl} / \mathrm{C}$, and $\mathrm{RuCl} / \mathrm{C}$. On the one hand, in Figure 2(a), it can be seen that the CNR carbonaceous support did not show new bands in the support treated with nitric acid (CNR-N). The bands at 665, 1583, and $3346 \mathrm{~cm}^{-1}$ correspond to ring deformation and $\mathrm{C}-\mathrm{O}$ stretching vibrations in phenolic groups, but in general, the lack of parallel behavior between the growth of bands in $1000-1350 \mathrm{~cm}^{-1}$ is attributed to primarily C-O stretching of ether groups, possibly furans, to $\mathrm{C}-\mathrm{OH}$ species [29], and to $\mathrm{O}-\mathrm{H}$ or C-N stretching [30].

On the other hand, in Figure 2(b), for all the catalysts, $\mathrm{PdN} / \mathrm{C}, \mathrm{PdCl} / \mathrm{C}, \mathrm{NiCl} / \mathrm{C}$, and $\mathrm{RuCl} / \mathrm{C}$, the following peaks can be seen in general: (i) a broad band centered at $3444 \mathrm{~cm}^{-1}$ which was assigned mainly to $\mathrm{O}-\mathrm{H}$ stretching, associated with the water absorbed on the surface of the material and hydroxylated groups; (ii) a $\mathrm{NH}_{2}$ stretching band located at $3600-3100 \mathrm{~cm}^{-1}$; and (iii) a C-H stretching band between 3000 and $2800 \mathrm{~cm}^{-1}$ [31]. In the $1350-1000 \mathrm{~cm}^{-1}$ range, the growth of bands for the $\mathrm{PdN} / \mathrm{C}$ catalyst can be 


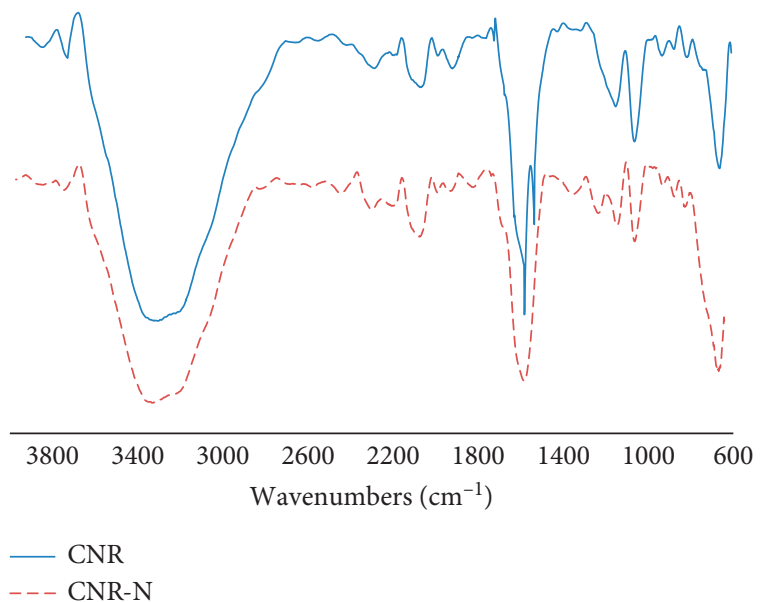

(a)

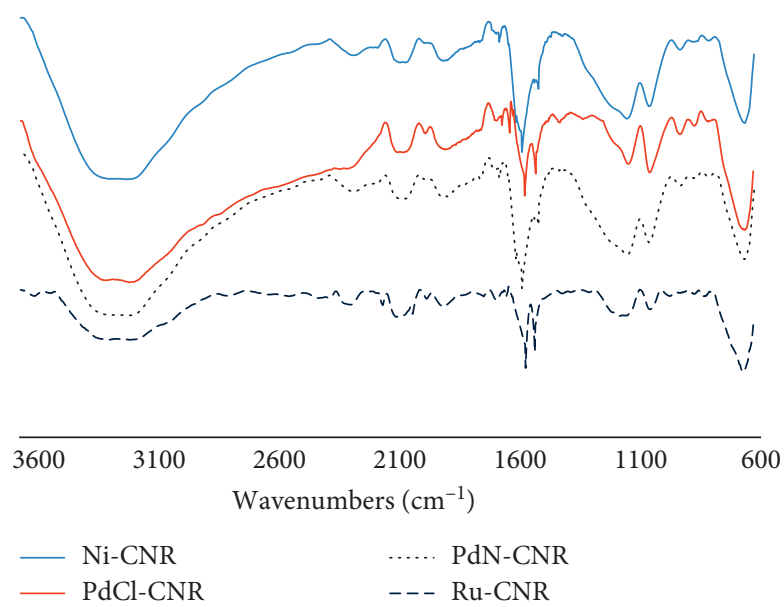

(b)

Figure 2: FTIR micro-ART spectra for the supports (a) CNR and CNR-N and for the catalysts (b) PdCl/C, $\mathrm{PdN} / \mathrm{C}, \mathrm{NiCl} / \mathrm{C}$, and $\mathrm{RuCl} / \mathrm{C}$.

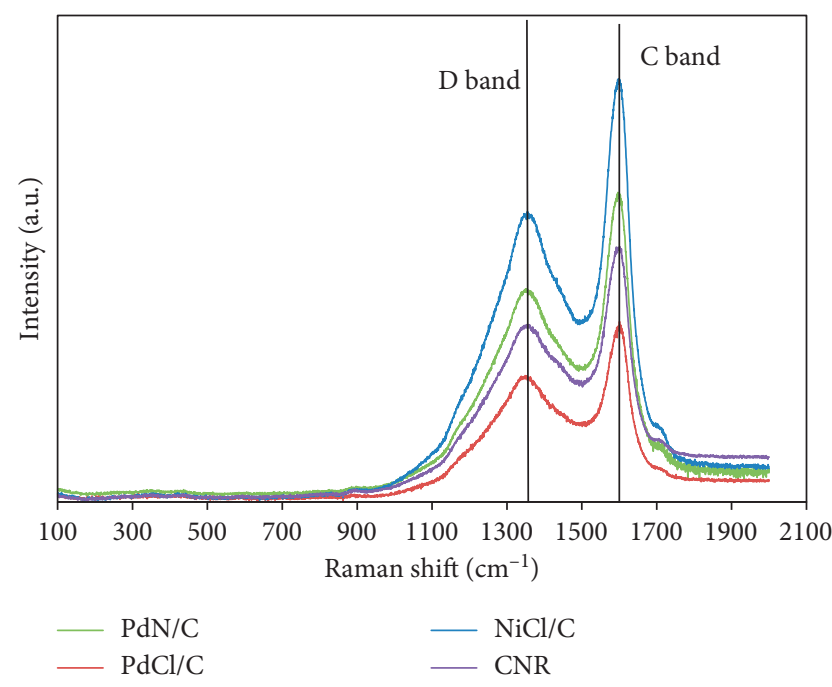

Figure 3: Raman spectroscopy for $\mathrm{PdN} / \mathrm{C}, \mathrm{PdCl} / \mathrm{C}$, and $\mathrm{NiCl} / \mathrm{C}$ catalysts.

attributed mainly to C-N stretching [32] because of the support treatment with nitric acid during the synthesis of the catalyst.

Figure 3 shows the Raman spectra of the catalysts and carbon support in the range of $100-2000 \mathrm{~cm}^{-1}$. The profile of all catalysts analyzed is very similar to the CNR support spectrum. Two intense bands at ca. $1600 \mathrm{~cm}^{-1}$ and ca. $1350 \mathrm{~cm}^{-1}$ are observed, which are the typical signals of the graphite spectrum. The first signal is known as the $G$ band associated with the graphitic order, and the second is named the $D$ band and is attributed to structural defects [32].

$\mathrm{PdN} / \mathrm{C}, \mathrm{PdCl} / \mathrm{C}, \mathrm{RuCl} / \mathrm{C}, \mathrm{NiCl} / \mathrm{C}$, and the CNR support diffractograms are shown in Figure 4. In this figure, it can be seen that there are no defined signals for the metallic samples or to the support, which could indicate the absence of the crystalline phases in all samples, or the crystals were very small ( $<100 \AA)$. The absence of the crystalline phase is a consequence of the low-metallic loadings of the samples, $0.4 \mathrm{wt} . \%$, low below the detection limit of the XRD equipment.

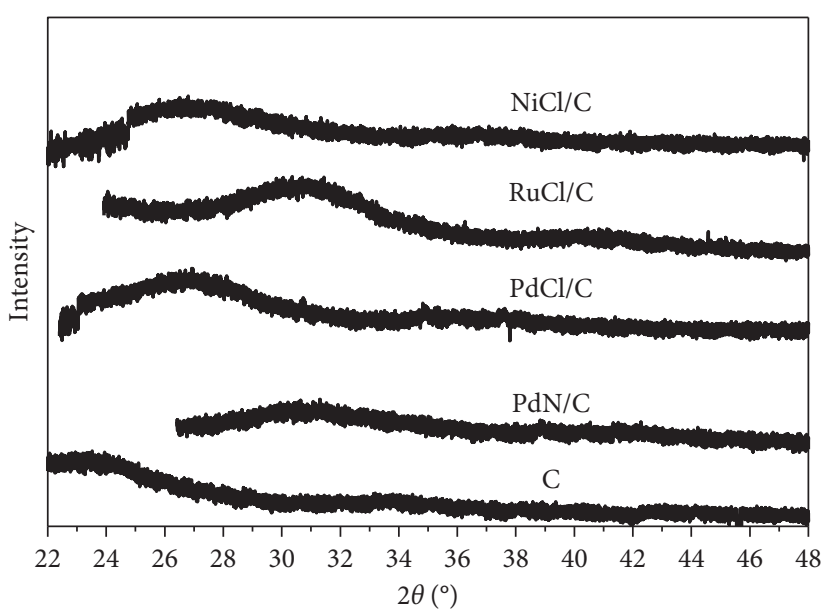

Figure 4: DRX diffractograms of $\mathrm{PdN} / \mathrm{C}, \mathrm{PdCl} / \mathrm{C}, \mathrm{RuCl} / \mathrm{C}$, and $\mathrm{NiCl} / \mathrm{C}$ catalysts treated in $\mathrm{H}_{2}$ at $393 \mathrm{~K}$ and the CNR support.

Figure 5 shows temperature-programmed reduction profiles of $\mathrm{PdN} / \mathrm{C}, \mathrm{PdCl} / \mathrm{C}, \mathrm{RuCl} / \mathrm{C}$, and $\mathrm{NiCl} / \mathrm{C}$ catalysts. In this figure, the TPR profile of CNR carbon is also presented for a comparative way. As can be seen in Figure 5, the support and the catalysts profiles present a broad peak with a maximum at ca. $870 \mathrm{~K}$, which can be attributed to the gasification of the carbonaceous support, the decomposition of chloride or nitrogen species, the reduction of superficial oxygenated groups of the support, or due to the possible presence of impurities (5-6\%), producing $\mathrm{CH}_{4}, \mathrm{CO}$, and/or $\mathrm{CO}_{2}$ [33-35]. de Miguel et al. [36], for carbonaceous supports, found these types of consumption at very high temperatures, between 923 and $1223 \mathrm{~K}$, associated with decomposition of superficial oxygenated groups $(\mathrm{C}[\mathrm{O}])$ that can liberate $\mathrm{CO}$ in the presence of a reductive stream. In Figure 5, it can be seen that, at temperatures higher than $700 \mathrm{~K}$, all metallic catalysts samples present very similar profile due to the reduction of surface groups of the carbonaceous support.

The palladium catalysts $(\mathrm{PdN} / \mathrm{C}$ and $\mathrm{PdCl} / \mathrm{C})$ presented at high temperatures a much wider peak profiles with respect 
TABLe 2: Metal loading, dispersion, particle diameter, XPS, initial reaction rate, and activity (TOF) results for the catalysts.

\begin{tabular}{|c|c|c|c|c|c|c|c|}
\hline \multirow{2}{*}{ Catalysts } & \multirow{2}{*}{ Metal loading (\%) } & \multirow{2}{*}{$D(\%)$} & \multirow{2}{*}{$d(\mathrm{~nm})$} & \multicolumn{2}{|c|}{ XPS } & \multirow{2}{*}{$r^{\circ}\left(\mathrm{mol} \cdot \mathrm{g}_{\mathrm{M}}^{-1} \cdot \mathrm{s}^{-1}\right)$} & \multirow{2}{*}{ TOF $\left(s^{-1}\right)$} \\
\hline & & & & $\mathrm{M} 3 \mathrm{~d}_{5 / 2} \mathrm{BE}(\mathrm{eV})$ & $\mathrm{Cl} / \mathrm{M}$ (at/at) & & \\
\hline $\mathrm{PdN} / \mathrm{C}$ & 0.39 & 48 & 2.4 & 335.2 & - & 0.077 & 17.0 \\
\hline $\mathrm{PdCl} / \mathrm{C}$ & 0.42 & 62 & 1.9 & 335.2 & 1.56 & 0.050 & 8.6 \\
\hline $\mathrm{RuCl} / \mathrm{C}$ & 0.41 & 20 & 5.3 & 282.1 & 2.96 & 0.056 & 28.5 \\
\hline $\mathrm{NiCl} / \mathrm{C}$ & 0.41 & 4 & 25.2 & 857.3 & 2.05 & 0.026 & 38.9 \\
\hline Lindlar & 5 & 2.5 & 46.4 & 337.2 & - & 0.003 & 13.5 \\
\hline
\end{tabular}

to the support, as can be observed in Figure 5, with a maximum at ca. $875 \mathrm{~K}$. No peaks are present at low reduction temperature, and this is because the palladium can be reduced by carbon at low temperature, even at room temperature as was observed by other authors [37]. In Figure 5, it can be seen that the peak above $700 \mathrm{~K}$ is more intense for $\mathrm{PdN} / \mathrm{C}$ and $\mathrm{NiCl} / \mathrm{C}$ catalysts. Besides, the TPR profile of the $\mathrm{NiCl} / \mathrm{C}$ sample shows a small peak at $610 \mathrm{~K}$ attributed to the reduction of $\mathrm{NiO}$ to $\mathrm{Ni}^{\circ}$ species, which indicates a weak metal-support interaction [38-40]. Lastly, for the ruthenium catalyst $(\mathrm{RuCl} / \mathrm{C})$, the $\mathrm{TPR}$ profile presents a signal with maximum at $610 \mathrm{~K}$, related to the reduction of ruthenium, $\mathrm{Ru}^{3+} \rightarrow \mathrm{Ru}^{2+} \rightarrow \mathrm{Ru}^{\circ}$, assigned to the reduction of the ruthenium chloride species [16, 35].

As an early conclusion, at the reduction temperature used during the preparation step of the catalysts (393 K, marked in Figure 5), the palladium metals on $\mathrm{PdCl} / \mathrm{C}$ and $\mathrm{PdN} / \mathrm{C}$ could be mostly as $\mathrm{Pd}^{\circ}$ species on the catalyst surface; meanwhile, nickel and ruthenium are present as $\mathrm{Ni}^{2+}$ and $\mathrm{Ru}^{3+}$ species.

Table 2 summarizes all the catalysts under study, the results of ICP, dispersion and particle diameter by hydrogen chemisorption, XPS, initial reaction rate, and activity TOF values. For a comparative study, the Lindlar catalyst was also included in Table 2. The metal loadings of the synthetized catalysts are ca. 0.4 wt. $\%$ in the final catalyst, while a concentration of 5 wt.\% of Pd was corroborated for commercial Lindlar. Dispersion values show the following order $\mathrm{PdCl} / \mathrm{C}>\mathrm{PdN} / \mathrm{C}>\mathrm{RuCl} / \mathrm{C}$, while $\mathrm{NiCl} / \mathrm{C}$ and Lindlar catalysts present extremely low $D$ values (lower than 5\%). Higher dispersions are favored by low loadings of the metallic precursor and by low pretreatment conditions used during the preparation of the catalysts [41]; besides, high surface areas and large pore volume of the carbonaceous materials usually favor very high dispersion of an active phase. All these factors avoid the sintering of the active phase. In our case, the highest dispersion of the Pd catalyst prepared from chlorinated precursor can be due to the presence of complex oxychlorinated species formed during the pretreatment step. The presence of these species improves the metal dispersion due to the greater interaction between these oxychlorinated species and the support as compared to the weaker one displayed by palladium(II) oxide (PdO) [42-44]. Furthermore, the PdN/C catalyst presents a dispersion of ca. 50\% attributed to the high concentration of carboxylic-type groups on the surface, as observed by TPD-MS analysis, that exert an electronic and geometrical effect over the nitrate precursor used. On the contrary, due to the high surface area, ruthenium particles would also be highly dispersed on these carbon supports

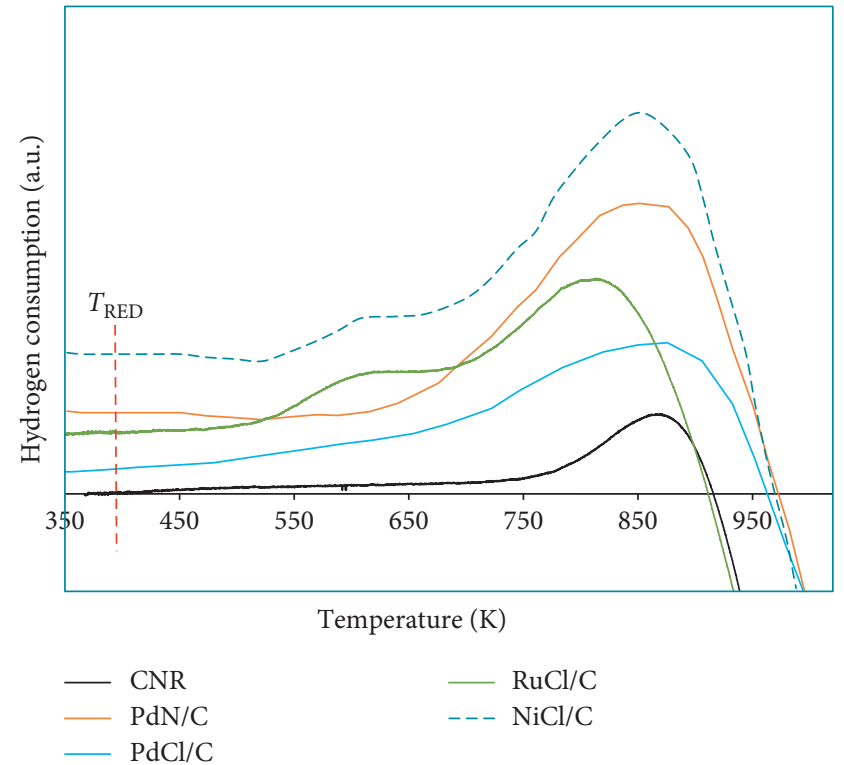

Figure 5: TPR profiles of $\mathrm{PdN} / \mathrm{C}, \mathrm{PdCl} / \mathrm{C}, \mathrm{RuCl} / \mathrm{C}$, and $\mathrm{NiCl} / \mathrm{C}$ catalysts and the CNR support.

[45]. However, there is no simple relationship between the value of the surface area of the activated carbon and the metal dispersion of the catalysts supported on activated carbon [46]. Some authors [47-51] reported the inhibition and drawbacks due to the use of $\mathrm{RuCl}_{3}$ as a precursor salt because the chloride from this salt is a poison for $\mathrm{CO}$ and $\mathrm{H}_{2}$ chemisorptions and may be partitioned between the metal and the support. In our case, the high degree of sintering of the ruthenium metal particles could be due to the fact that, during the pretreatment process, no oxychlorinated species interacting with the support are formed, as noted earlier while studying ruthenium catalysts of different metal contents over the alumina support $[12,21]$. The low dispersion of nickel is a characteristic when this metal is used to prepare inorganic or carbonaceous catalysts [52, 53].

From the $\mathrm{H}_{2}$ chemisorption results, the metal particle size $(d)$ was determined on assuming a spherical particle in accordance with Badano et al. [21]. The particle size order is $\mathrm{PdCl} / \mathrm{C}<\mathrm{PdN} / \mathrm{C}<\mathrm{RuCl} / \mathrm{C} \ll \mathrm{NiCl} / \mathrm{C} \ll$ Lindlar. The smallest particle size of $\mathrm{PdCl} / \mathrm{C}$ catalysts is due to the higher surface interaction between $\mathrm{Pd}^{\delta+} \mathrm{O}_{x} \mathrm{Cl}_{y}$ and oxygenated groups of the carbonaceous support, as observed earlier when alumina was used as a support [21]. The higher particle size of $\mathrm{NiCl} / \mathrm{C}$ could be related with the higher structural defects observed by the Raman spectra in Figure 3. 


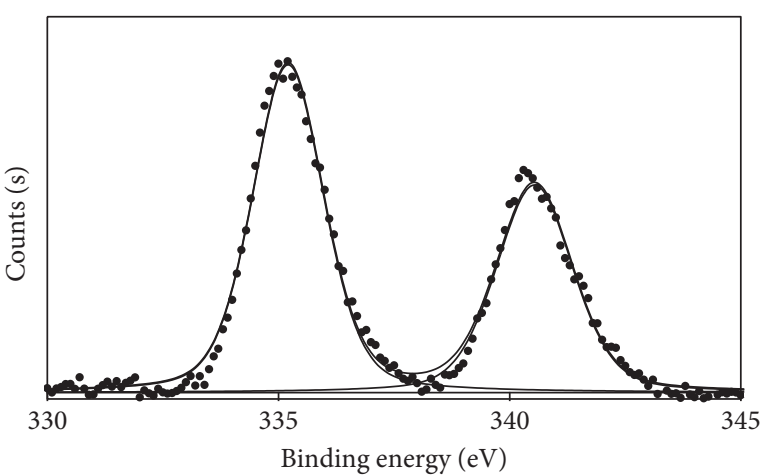

(a)

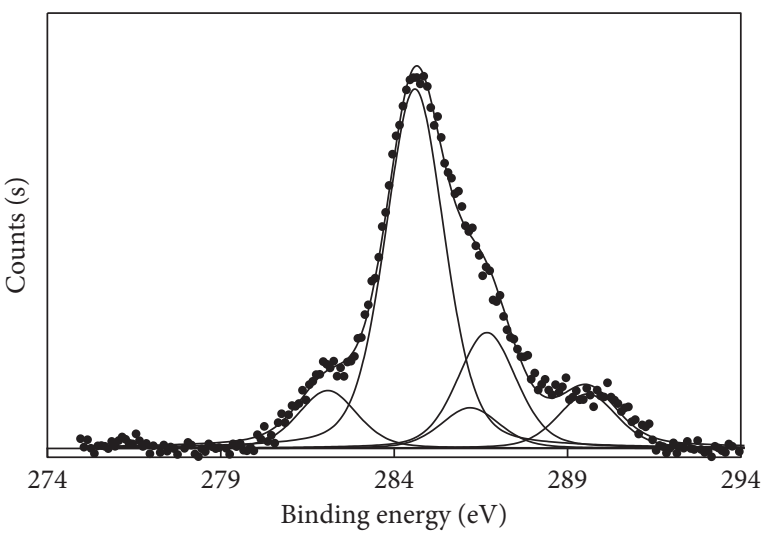

(c)

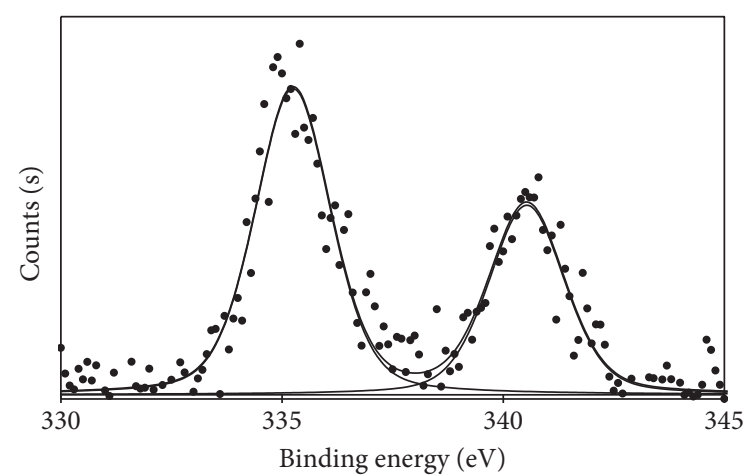

(b)

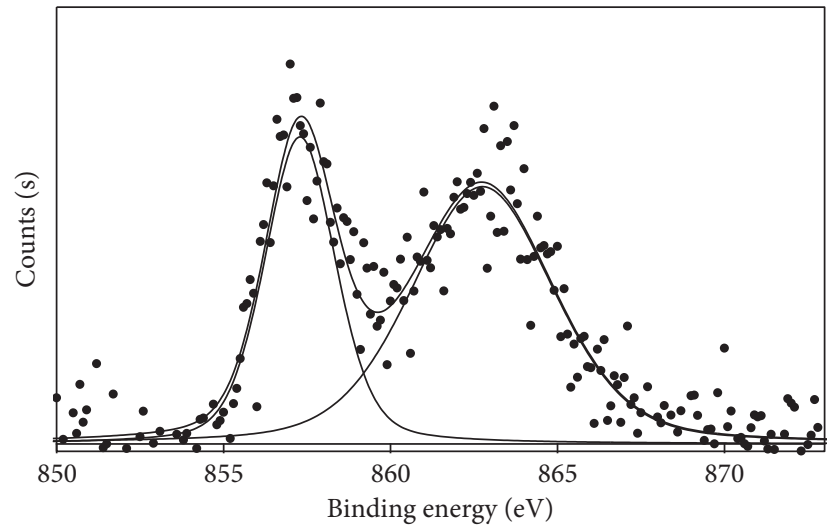

(d)

Figure 6: XPS spectra of BE Pd 3d for (a) PdN/C, (b) PdCl/C, (c) $\mathrm{RuCl} / \mathrm{C}$, and (d) NiCl/C catalysts treated in $\mathrm{H}_{2}$ at $393 \mathrm{~K}$.

Figure 6 shows the XPS spectra of the Pd $3 d_{5 / 2}$ band for $\mathrm{PdN} / \mathrm{C}$ and $\mathrm{PdCl} / \mathrm{C}, \mathrm{Ru} 3 \mathrm{~d}_{5 / 2}$ band for $\mathrm{RuCl} / \mathrm{C}$, and Ni $2 \mathrm{p}_{3 / 2}$ band for the $\mathrm{NiCl} / \mathrm{C}$ catalyst. Besides, the XPS spectra of the catalysts prepared from chlorine precursors $(\mathrm{PdCl} / \mathrm{C}$, $\mathrm{RuCl} / \mathrm{C}$, and $\mathrm{NiCl} / \mathrm{C}$ ) show a $\mathrm{Cl} 2 \mathrm{p}_{3 / 2}$ peak at ca. $199.4 \mathrm{eV}$ that corresponds to surface chloride species [54] that were not completely eliminated after reduction because of the high adsorption capacity of the carbonaceous material used. The maximum binding energy (BE) of $\mathrm{Pd}$ and $\mathrm{Ru} 3 \mathrm{~d}_{5 / 2}$, Ni $2 \mathrm{p}_{3 / 2}$ peaks, and $\mathrm{Cl} / \mathrm{M}$ atomic ratios are also listed in Table 2.

XPS results in Figure 6 show that both palladium catalysts present a Pd $3 \mathrm{~d}_{5 / 2}$ peak at $335.2 \mathrm{eV}$, which can be attributed to $\mathrm{Pd}^{\delta+}(\delta \approx 0)[16,54]$. Figure 6 also shows the spectra of palladium catalysts and the $3 \mathrm{~d}_{3 / 2}$ peak doublet shifted $5.2 \mathrm{eV}$ with respect to the $3 \mathrm{~d}_{5 / 2}$ peak. No nitrogen was detected by XPS on the Pd catalyst prepared from the nitrate precursor. On the contrary, for the $\mathrm{PdCl} / \mathrm{C}$ sample, the $\mathrm{Cl} / \mathrm{Pd}$ atomic ratio was 1.56 , confirming that chloride is present even after the reduction treatment. This could be attributed to the high absorption capacity of the carbon support. The chlorine content does not affect the palladium surface as it is totally reduced on the $\mathrm{PdCl} / \mathrm{C}$ catalyst.

In the case of ruthenium, the $\mathrm{BE}$ reference is difficult because the $\mathrm{Ru} 3 \mathrm{~d}$ peaks appear at the same region than the $\mathrm{C}$ 1s peak. There are also discrepancies in the BE reported in the literature for ruthenium compounds. The $\mathrm{Ru} 3 \mathrm{~d}_{5 / 2}$ signal for the $\mathrm{RuCl} / \mathrm{C}$ catalyst was observed at $282.1 \mathrm{eV}$ corresponding to ruthenium electrodeficient species as $\mathrm{RuCl}_{3}$
[54]. For this catalyst, after the temperature pretreatments, the superficial atomic ratio $\mathrm{Cl} / \mathrm{Ru}$ was 2.96 .

According to the bibliography $[54,55]$, the $\mathrm{Ni} 2 \mathrm{p}_{3 / 2}$ signal appears at $852.5 \mathrm{eV}$ for $\mathrm{Ni}^{\circ}$ species. For the $\mathrm{NiCl} / \mathrm{C}$ catalyst, the two signals were observed in the spectrum of Figure 6 at 857.3 and $862.7 \mathrm{eV}$. The first peak could be assigned to the electrodeficient nickel species $\left(\mathrm{Ni}^{n+}\right.$, with $\left.n \rightarrow 2\right)$, probably corresponding to nickel interacting with the support [54-56], while the second peak corresponds to the characteristic shakeup satellite structure of $\mathrm{Ni}$ (II) $[55,57,58]$. This catalyst also presents a high $\mathrm{Cl} / \mathrm{Ni}$ atomic ratio (2.05) as a consequence of the adsorption capacity or the carbonaceous support.

For the Lindlar catalyst, in Table 2 , the main peaks at $335.2 \mathrm{eV}(69 \%$, at/at) and $336.9 \mathrm{eV}(31 \%$, at/at) are also registered, assigned to $\mathrm{Pd}^{\delta+}$ and electrodeficient $\mathrm{Pd}^{n+}$ species (with $\delta \rightarrow 0$ and $n \rightarrow 2$ ), respectively [53]. On the contrary, on the Lindlar catalyst, also two peaks of the $\mathrm{Pb} 4 \mathrm{f}_{7 / 2}$ spectrum at $136.8 \mathrm{eV}(20 \%$, at/at) and $138.6(80 \%$, at/at $)$ were attributed to $\mathrm{Pb}$ and $\mathrm{Pb}(\mathrm{OAc})_{2}$, respectively [53].

In Figure 7, TEM micrographs of the carbonaceous catalysts are shown. The metal particle size for the $\mathrm{PdCl} / \mathrm{C}$ catalyst is between 1 and $4 \mathrm{~nm}$, presenting a high concentration of $2 \mathrm{~nm}$ Pd particles on the carbon surface. For $\mathrm{PdN} / \mathrm{C}$, the main palladium particle size is between 4 and $8 \mathrm{~nm}$. The particle sizes of $\mathrm{Ru}$ on $\mathrm{RuCl} / \mathrm{C}$ are mainly between 1 and $5 \mathrm{~nm}$, although several bigger particles were observed on the micrographs. Besides, the $\mathrm{NiCl} / \mathrm{C}$ catalyst presented the highest particle sizes between 25 and $40 \mathrm{~nm}$. 


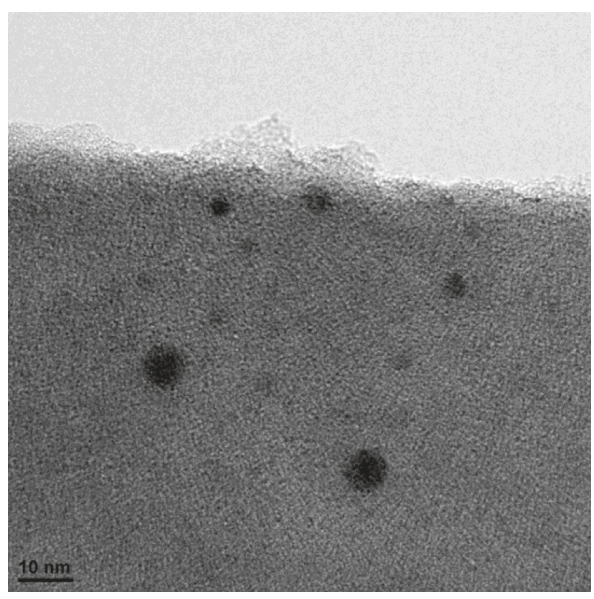

(a)

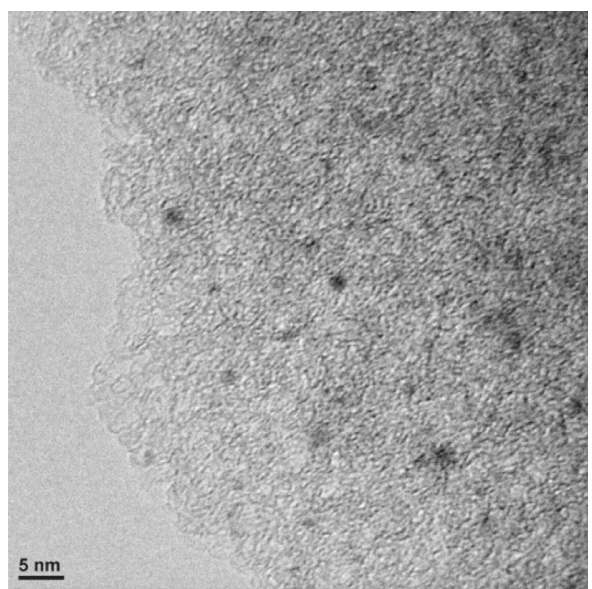

(c)

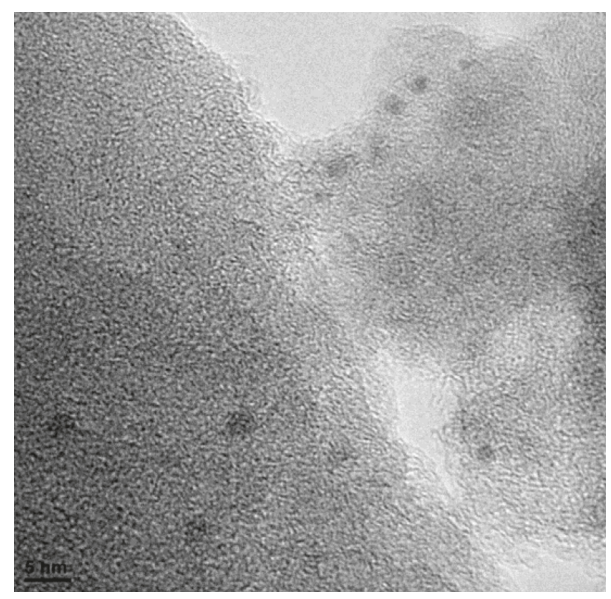

(b)

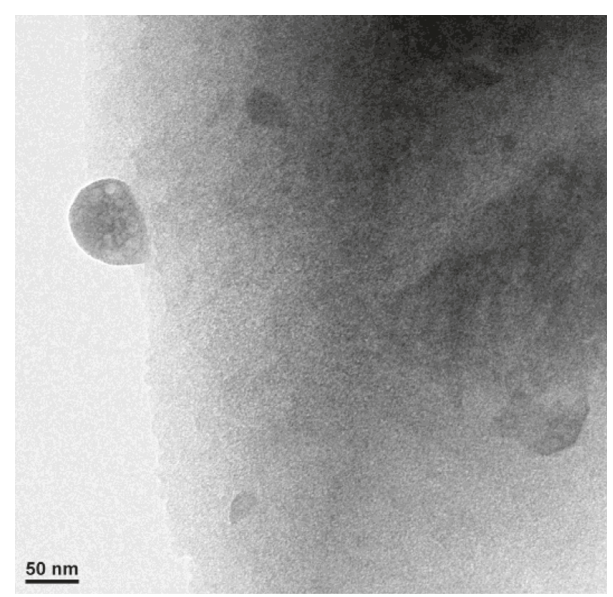

(d)

Figure 7: TEM Images for (a) PdN/C, (b) PdCl/C, (c) $\mathrm{RuCl} / \mathrm{C}$, and (d) $\mathrm{NiCl} / \mathrm{C}$ catalysts.

3.2. Catalytic Tests. The catalytic performance during the selective hydrogenation of 1-heptyne for $\mathrm{PdN} / \mathrm{C}, \mathrm{PdCl} / \mathrm{C}$, $\mathrm{RuCl} / \mathrm{C}$, and $\mathrm{NiCl} / \mathrm{C}$ catalysts is shown in Figure 8. 1heptyne total conversion (\%) and selectivity to 1-heptene (\%) as a function of time ( $\mathrm{min}$ ) were plotted in this figure for all the studied catalysts. All the catalysts were active during the hydrogenation of 1-heptyne and presented high selectivity to 1-heptene, the desired product.

Besides, in Figure 9, 1-heptyne total conversion (\%) and selectivity to 1 -heptene $(\%)$ as a function of time (min) for the commercial Lindlar catalyst used as a reference is shown.

According to Figures 8 and 9 the order of selectivities to the corresponding alkene was:

$$
\mathrm{PdCl} / \mathrm{C}<\mathrm{PdN} / \mathrm{C} \cong \mathrm{RuCl} / \mathrm{C}<\text { Lindlar }<\mathrm{NiCl} / \mathrm{C}
$$

In order to compare the performance of the catalytic systems, the initial reaction rate of hydrogenation of 1-heptyne $\left(r_{\mathrm{A}}^{0}\right)$ was estimated for all the catalysts using the following formula:

$$
r_{\mathrm{A}}^{0}=\frac{V \cdot C_{\mathrm{A}}^{0}}{W_{\mathrm{M}}} \cdot\left(\frac{\partial X_{\mathrm{A}}}{\partial t}\right)_{t=0},
$$

where $r_{\mathrm{A}}^{0}$ is the initial 1-heptyne reaction rate $\left(\mathrm{mol} \cdot \mathrm{g}_{\mathrm{M}}{ }^{-1} \cdot \mathrm{s}^{-1}\right)$, $\left(\partial X_{\mathrm{A}} / \partial t\right)_{t=0}$ is the tangent value of the 1-heptyne total conversion versus time curve at $t=0, C_{\mathrm{A}}^{0}$ is the initial concentration of 1-heptyne $\left(\mathrm{mol} \cdot \mathrm{L}^{-1}\right), W_{\mathrm{M}}$ is the mass of the metal $(\mathrm{Pd}, \mathrm{Ru}$, or $\mathrm{Ni})$ in the catalyst $(\mathrm{g}), V$ is the reaction volume (L), and $t$ is the reaction time (s).

From these initial reaction rates of 1-heptyne hydrogenation, TOF values were calculated for all the catalysts and are summarized in Table 2. For hydrogenation reactions, TOF values between $10^{-2}$ and $10^{2}$ indicate a structure-insensitive system, not influenced by particle size $[59,60]$, so the differences in activities and selectivities between the catalysts may be associated with geometrical and/or geometrical effects. The order of activities of low-loaded catalysts is

$$
\mathrm{PdCl} / \mathrm{C}<\text { Lindlar }<\mathrm{PdN} / \mathrm{C}<\mathrm{RuCl} / \mathrm{C}<\mathrm{NiCl} / \mathrm{C}
$$

The effect of the precursor salt was studied by comparing $\mathrm{PdCl} / \mathrm{C}$ and $\mathrm{PdN} / \mathrm{C}$ catalysts. The results obtained for these catalysts show differences in both activity and selectivity. For the catalyst synthetized from palladium nitrate as the precursor salt, the obtained TOF was $17 \mathrm{~s}^{-1}$ versus the activity of palladium chloride precursor salt $8.6 \mathrm{~s}^{-1}$. That is, each active site of the $\mathrm{PdN} / \mathrm{C}$ catalyst is almost two times more active than that of $\mathrm{PdCl} / \mathrm{C}$. As observed by XPS and RTP, both catalysts have $\mathrm{Pd}^{\delta+}$ (with $\delta \cong 0$ ) as the active site, so no 


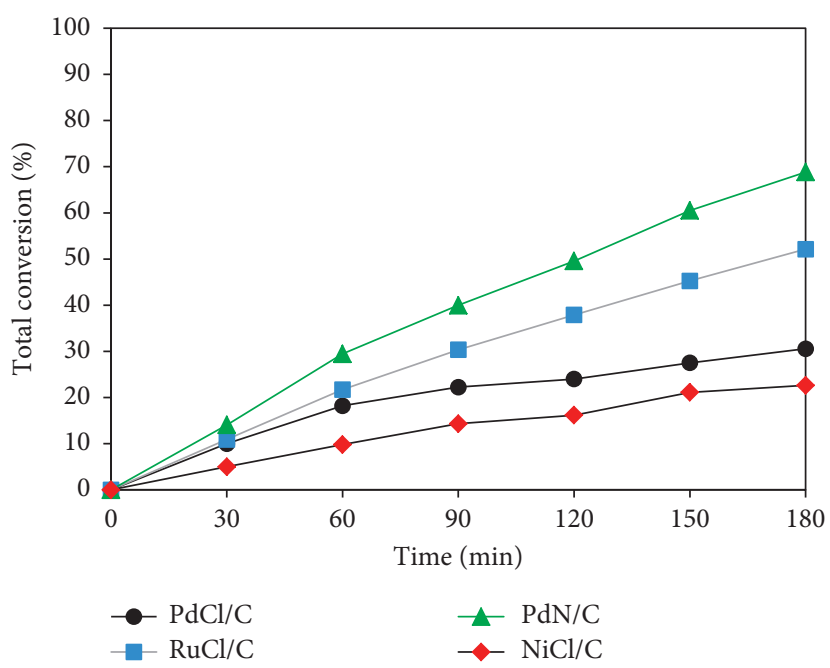

(a)

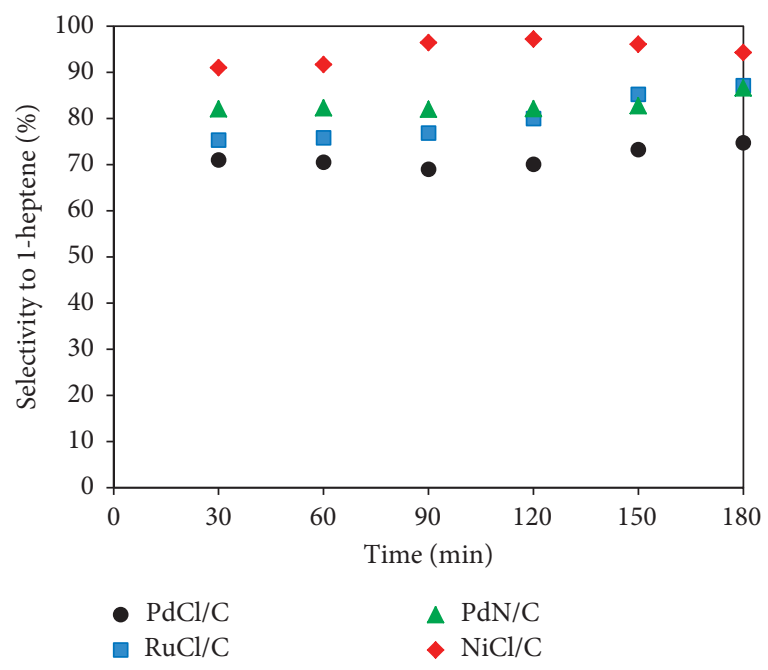

(b)

Figure 8: Total conversion (a) and selectivity to 1-heptene (b) versus time (min) for $\mathrm{PdN} / \mathrm{C}, \mathrm{PdCl} / \mathrm{C}, \mathrm{RuCl} / \mathrm{C}$, and $\mathrm{NiCl} / \mathrm{C}$ catalysts pretreated in $\mathrm{H}_{2}$ at $393 \mathrm{~K}$.

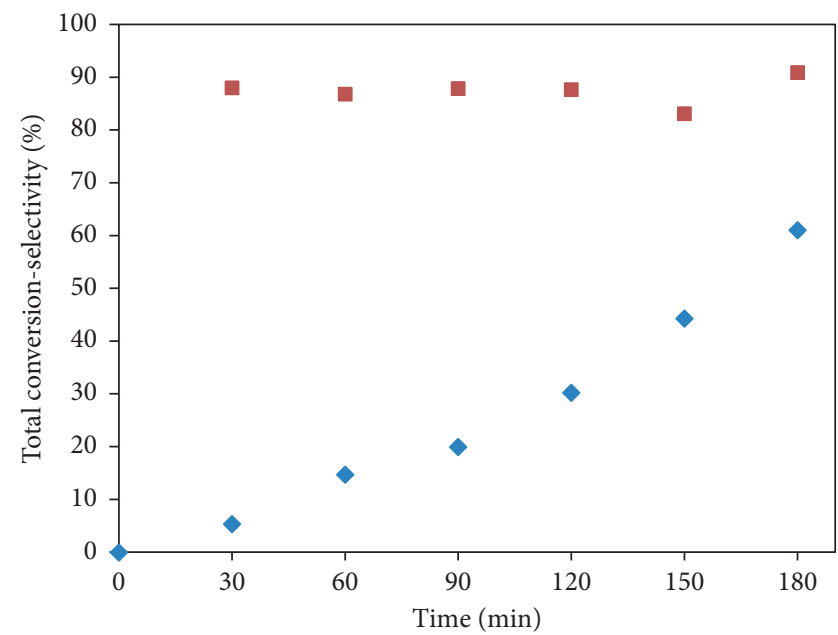

FIgURE 9: Total conversion $(\diamond)$ and selectivity to 1-heptene ( $\square$ ) versus time $(\mathrm{min})$ for the Lindlar catalyst (reproduced from Lederhos et al. [52], under the Creative Commons Attribution License/public domain).

electronic effects are generated by the metallic phase; besides as observed by Raman, quite higher structural effects were found on $\mathrm{PdN} / \mathrm{C}$ than on the $\mathrm{PdCl} / \mathrm{C}$ sample. When comparing the catalytic behavior of the different Pd precursors, higher selectivities to 1-heptene were obtained when palladium nitrate was used, ca. $86 \%$ at $180 \mathrm{~min}$, while for $\mathrm{PdCl} / \mathrm{C}$ selectivities, ca. $70 \%$ was obtained.

In Figure 10, the main superficial groups present on carbonaceous supports are summarized. Between them carboxylic groups by heterolytic rupture of the $\mathrm{O}-\mathrm{H}$ bond, could favor the adsorption of the cationic metallic precursors $\mathrm{M}^{n+}$. In our case, the higher distribution of carboxylic and lactone groups on the surface of PdN/C could favor the adsorption of $\mathrm{Pd}^{2+}$, and its reduction to $\mathrm{Pd}^{\circ}$ (as detected by XPS and TPR) during the pretreatment step: for $1 \mathrm{~h}$ at $393 \mathrm{~K}$ under a hydrogen stream.

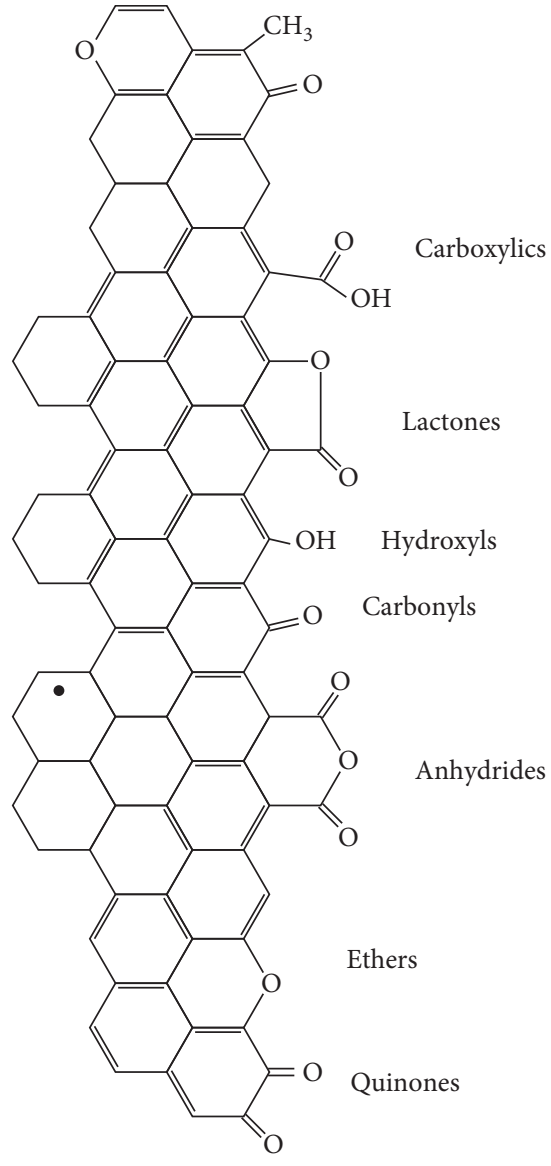

FIGURE 10: Schematic representation of the main superficial groups found on a carbonaceous supports.

Also, the high concentration of carboxylic groups favors the high dispersion of the active sites and the small particle sizes. So, the observed differences in activity between PdN/C and $\mathrm{PdCl} / \mathrm{C}$ could be originated, at least in part, by geometrical 
effects due to higher structural defects (as noted in D-bands on the Raman spectra) and electronic effects originated by the high concentration of carboxylic superficial groups on PdN/C (the favorable effect) and high remnants of chloride on $\mathrm{PdCl} / \mathrm{C}$ catalysts (the negative effect). Besides, differences in selectivity between the $\mathrm{PdN} / \mathrm{C}$ and $\mathrm{PdCl} / \mathrm{C}$ catalysts could be caused on the one hand to the electronic and geometrical effects that favors the formation of 1-heptene and on the other hand to higher amount of carbonaceous superficial groups that favors the desorption of the alkene, avoiding its overhydrogenation, while alkyne is present in the reaction media.

When analyzing the effect of the metal type used to synthesize the carbonaceous catalysts, $\mathrm{PdCl} / \mathrm{C}, \mathrm{RuCl} / \mathrm{C}$, and $\mathrm{NiCl} / \mathrm{C}$, the highest activity and selectivity were achieved when the supported metal is nickel, a very low cost precursor salt. The high activity and selectivity of $\mathrm{NiCl} / \mathrm{C}$ could be related to electronic or geometrical effects of active sites, which would control the dissociative adsorption of hydrogen being this the controlling step [61], and/or to the aromatic superficial groups of the support that would preferentially adsorb remaining 1heptyne desorbing 1-heptene from the reaction media, so avoiding its total hydrogenation to the alkane.

\section{Conclusions}

The effect of metallic salt and the kind of metal was studied using a carbonaceous support. A series of low-loaded catalysts supported on an activated carbon (ca. $0.4 \mathrm{wt} . \%$ ) were synthetized by the incipient wetness technique. Nanoparticles of palladium, ruthenium, and nickel were deposited using $\mathrm{Pd}\left(\mathrm{NO}_{3}\right)_{2}, \mathrm{PdCl}_{2}$, $\mathrm{RuCl}_{3}$, and $\mathrm{NiCl}_{2}$ aqueous acidic solutions as precursor salts. The catalysts were pretreated under moderate conditions.

$\mathrm{PdN} / \mathrm{C}, \mathrm{PdCl} /, \mathrm{RuCl} / \mathrm{C}$, and $\mathrm{NiCl} / \mathrm{C}$ were characterized by ICP, TPD, FTIR micro-ATR, Raman, XRD, TPR, hydrogen chemisorption, XPS, and TEM.

All the catalytic systems were assessed during the selective hydrogenation of 1-heptyne, a medium-chain alkyne under moderate operational conditions: $303 \mathrm{~K}, 150 \mathrm{kPa}$, and $800 \mathrm{rpm}$ during $180 \mathrm{~min}$. The catalysts were active and selective to 1-heptene. The order of activity and selectivity found was $\mathrm{NiCl} / \mathrm{C}>\mathrm{RuCl} / \mathrm{C}>\mathrm{PdCl} / \mathrm{C}$. Geometrical and electronic effects over the $\mathrm{NiCl} / \mathrm{C}$ catalyst favors alkyne adsorption and 1heptene desorption in the reaction media, avoiding alkyne total hydrogenation to the alkane. Besides, the PdN/C catalyst is more active and selective than $\mathrm{PdCl} / \mathrm{C}$ due to geometrical and electronic effects, and the first ones are caused by structural defects (observed by Raman), while the seconds ones are originated by the high loading of carboxylic superficial on $\mathrm{PdN} / \mathrm{C}$ and the chloride remnants on $\mathrm{PdCl} / \mathrm{C}$ catalysts (as observed by TPD-MS and XPS, resp.).

\section{Data Availability}

The data used to support the findings of this study are available from the corresponding author upon request.

\section{Conflicts of Interest}

The authors declare that they have no conflicts of interest.

\section{Acknowledgments}

The financial assistance of UNL (CAI+D), CONICET (PIP 457), and ANPCyT (PICT-2013-2021 and PICT-2016-1453) is greatly acknowledged.

\section{References}

[1] A. Molnár, A. Sárkány, and M. Varga, "Hydrogenation of carbon-carbon multiple bonds: chemo-, regio- and stereoselectivity," Journal of Molecular Catalysis A: Chemical, vol. 173, no. 1-2, pp. 185-221, 2001.

[2] D. Teschner, E. Vass, M. Hävecker et al., "Alkyne hydrogenation over Pd catalysts: a new paradigm," Journal of $\mathrm{Ca}$ talysis, vol. 242, no. 1, pp. 26-37, 2006.

[3] P. Kačer, M. Kuzma, and L. Ćervenỳ, "The molecular structure effects in hydrogenation of cycloalkylsubstituted alkynes and alkenes on platinum and palladium catalysts," Applied Catalysis A: General, vol. 259, no. 2, pp. 179-183, 2004.

[4] B. M. Choudary, M. Lakshmi Kantam, N. Mahender Reddy et al., "Hydrogenation of acetylenics by Pd-exchanged mesoporous materials," Applied Catalysis A: General, vol. 181, no. 1, pp. 139-144, 1999.

[5] J. Lei, L. B. Su, K. Zeng et al., "Recent advances of catalytic processes on the transformation of alkynes into functional compounds," Chemical Engineering Science, vol. 171, pp. 404-425, 2017.

[6] C. Oger, L. Balas, T. Durand, and J.-M. Galano, “Are alkyne reductions chemo-, regio-, and stereoselective enough to provide pure (Z)-olefins in polyfunctionalized bioactive molecules?," Chemical Reviews, vol. 113, no. 3, pp. 1313-1350, 2013.

[7] G. A. Attard, J. A. Bennett, I. Mikheenko et al., "Semihydrogenation of alkynes at single crystal, nanoparticle and biogenic nanoparticle surfaces: the role of defects in Lindlartype catalysts and the origin of their selectivity," Faraday Discussions, vol. 162, pp. 57-75, 2013.

[8] S. Nishimura, Handbook of Heterogeneous Catalytic Hydrogenation for Organic Synthesis, Wiley, New York, NY, USA, 2001.

[9] B. Chen, U. Dingerdissen, J. G. E. Krauter et al., "New developments in hydrogenation catalysis particularly in synthesis of fine and intermediate chemicals," Applied Catalysis A: General, vol. 280, no. 1, pp. 17-46, 2005.

[10] H. Lindlar and R. Dubuis, "Palladium catalyst for partial reduction of acetylenes," Organic Syntheses, vol. 46, pp. 89-92, 1966.

[11] C. Lederhos, P. C. L’Argentière, and N. S. Fígoli, “1-heptyne selective hydrogenation over Pd supported catalysts," Industrial \& Engineering Chemistry Research, vol. 44, no. 6, pp. 1752-1766, 2005.

[12] C. Lederhos, P. C. L’Argentière, F. Coloma-Pascual, and N. S. Fígoli, "A study about the effect of the temperature of hydrogen treatment on the properties of $\mathrm{Ru} / \mathrm{Al} 2 \mathrm{O} 3$ and $\mathrm{Ru} / \mathrm{C}$ and their catalytic behavior during 1-heptyne semi-hydrogenation," Catalysis Letters, vol. 110, no. 1-2, pp. 23-28, 2006.

[13] E. Auer, A. Freund, J. Pietsch, and T. Tacke, "Carbons as supports for industrial precious metal catalysts," Applied Catalysis A: General, vol. 173, no. 2, pp. 259-271, 1998.

[14] F. Rodríguez-Reinoso, "The role of carbon materials in heterogeneous catalysis," Carbon, vol. 36, no. 3, pp. 159-175, 1998.

[15] J. L. Figueiredo, M. F. R. Pereira, M. M. A. Freitas, and J. J. M. Orfão, "Modification of the surface chemistry of activated carbons," Carbon, vol. 37, no. 9, pp. 1379-1389, 1999. 
[16] C. R. Lederhos, J. M. Badano, N. Carrara et al., "Metal and precursor effect during 1-heptyne selective hydrogenation using an activated carbon as support," The Scientific World Journal, vol. 2013, Article ID 528453, 9 pages, 2013.

[17] J. Okal, M. Zawadzki, L. Kępiński, L. Krajczyk, and W. Tylus, "The use of hydrogen chemisorption for the determination of $\mathrm{Ru}$ dispersion in $\mathrm{Ru} / \gamma$-alumina catalysts," Applied Catalysis A: General, vol. 319, pp. 202-209, 2007.

[18] C.-B. Wang, H.-K. Lin, and C.-M. Ho, "Effects of the addition of titania on the thermal characterization of aluminasupported palladium," Journal of Molecular Catalysis A: Chemical, vol. 180, no. 1-2, pp. 285-291, 2002.

[19] F. Pompeo, N. N. Nichio, M. M. V. M. Souza, D. V. Cesar, O. A. Ferretti, and M. Schmal, "Study of Ni and Pt catalysts supported on $\alpha-\mathrm{Al}_{2} \mathrm{O}_{3}$ and $\mathrm{ZrO}_{2}$ applied in methane reforming with $\mathrm{CO}_{2}$," Applied Catalysis A: General, vol. 316, no. 2, pp. 175-183, 2007.

[20] T. Paryjczac and J. A. Szymura, "Electron microscopic and chemisorption comparison studies on the metal dispersion of $\mathrm{Pd}, \mathrm{Rh}$, and Ir supported catalysts," Zeitschrift für Anorganische und Allgemeine Chemie, vol. 449, no. 1, pp. 105-114, 1979.

[21] J. M. Badano, M. Quiroga, C. Betti, C. Vera, S. Canavese, and F. Coloma-Pascual, "Resistance to sulfur and oxygenated compounds of supported $\mathrm{Pd}, \mathrm{Pt}, \mathrm{Rh}, \mathrm{Ru}$ catalysts," Catalysis Letters, vol. 137, no. 1-2, pp. 35-44, 2010.

[22] J. J. F. Scholten, A. P. Pijpers, and A. M. L. Hustings, "Surface characterization of supported and nonsupported hydrogenation catalysts," Catalysis Reviews, vol. 27, no. 1, pp. 151-206, 1985.

[23] R. J. Matyi, L. H. Schwartz, and J. B. Butt, "Particle size, particle size distribution, and related measurements of supported metal catalysts," Catalysis Reviews, vol. 29, no. 1, pp. 41-99, 1987.

[24] S. Shin, J. Jang, S.-H. Yoon, and I. Mochida, "A study on the effect of heat treatment on functional groups of pitch based activated carbon fiber using FTIR," Carbon, vol. 35, no. 12, pp. 1739-1743, 1997.

[25] R. Borade, A. Sayari, A. Adnot, and S. Kaliaguine, "Characterization of acidity in ZSM-5 zeolites: an X-ray photoelectron and IR spectroscopy study," Journal of Physical Chemistry, vol. 94, no. 15, pp. 5989-5994, 1990.

[26] D. Liprandi, M. Quiroga, E. Cagnola, and P. L’Argentière, “A new more sulfur-resistant rhodium complex as an alternative to the traditional Wilkinson's catalyst," Industrial \& Engineering Chemistry Research, vol. 41, no. 19, pp. 4906-4910, 2002.

[27] S. Hu and Y. Chen, "Partial hydrogenation of benzene: a review," Chinese Journal of Chemical Engineering, vol. 29, pp. 387-396, 1998.

[28] J. A. Díaz-Auñón, M. C. Román-Martínez, C. SalinasMartínez de Lecea et al., " $\left[\mathrm{PdCl}_{2}\left(\mathrm{NH}_{2}\left(\mathrm{CH}_{2}\right) 12 \mathrm{CH}_{3}\right)_{2}\right]$ supported on an active carbon: effect of the carbon properties on the catalytic activity of cyclohexene hydrogenation," Journal of Molecular Catalysis A: Chemical, vol. 153, no. 1-2, pp. 243-256, 2000.

[29] B. J. Meldrum and C. H. Rochester, "In situ infrared study of the surface oxidation of activated carbon in oxygen and carbon dioxide," Journal of the Chemical Society, Faraday Transactions, vol. 86, no. 5, pp. 861-865, 1990.

[30] R. M. Silverstein, G. Clayton Basler, and T. C. Morril, Spectrometric Identification of Organic CompoundsChapter III, Wiley, Wiley, New York, NY, USA, 5th edition, 1991.

[31] C. J. Pouchert, The Aldrich Library of Infrared Spectra, Wiley, New York, NY, USA, 3rd edition, 1981.
[32] R. Haritha Gangupomu, M. L. Sattler, and D. Ramirez, "Comparative study of carbon nanotubes and granular activated carbon: physicochemical properties and adsorption capacities," Journal of Hazardous Materials, vol. 302, pp. 362-374, 2016.

[33] L. Oliviero, J. Barbier Jr., D. Duprez, A. Guerrero-Ruiz, B. Bachiller-Baeza, and I. Rodŕ'guez-Ramos, "Catalytic wet air oxidation of phenol and acrylic acid over $\mathrm{Ru} / \mathrm{C}$ and $\mathrm{Ru}-\mathrm{CeO}_{2} /$ C catalysts," Applied Catalysis B: Environmental, vol. 25, no. 4, pp. 267-275, 2000.

[34] J. Krishna Murthy, S. Chandra Shekar, V. Siva Kumar, and K. S. Rama Rao, "Highly selective zirconium oxychloride modified $\mathrm{Pd} / \mathrm{C}$ catalyst in the hydrodechlorination of dichlorodifluoromethane to difluoromethane," Catalysis Communications, vol. 3, no. 4, pp. 145-149, 2002.

[35] F. Pinna, M. Signoretto, G. Strukul, A. Benedetti, M. Malentacchi, and N. Pernicone, "Ruthenium as a dispersing agent in carbon-supported palladium," Journal of Catalysis, vol. 155, no. 1, pp. 166-169, 1995.

[36] S. R. de Miguel, O. A. Scelza, M. C. Román-Martínez, C. Salinas-Martínez de Lecea, D. Cazorla-Amorós, and A. Linares-Solano, "States of $\mathrm{Pt}$ in $\mathrm{Pt} / \mathrm{C}$ catalyst precursors after impregnation, drying and reduction steps," Applied Catalysis A: General, vol. 170, no. 1, pp. 93-103, 1998.

[37] S. R. de Miguel, J. I. Vilella, E. L. Jablonski, O. A Scelza, C. Salinas-Martinez de Lecea, and A. Linares-Solano, "Preparation of Pt catalysts supported on activated carbon felts (ACF)," Applied Catalysis A: General, vol. 232, no. 1-2, pp. 237-246, 2002.

[38] F. Cardenas-Lizana, S. Gómez-Quero, and M. A. Keane, "Clean production of chloroanilines by selective gas phase hydrogenation over supported Ni catalysts," Applied Catalysis A: General, vol. 334, no. 1-2, pp. 199-206, 2008.

[39] P. Kim, H. Kim, J. B. Joo, W. Kim, I. K. Song, and J. Yi, “Effect of nickel precursor on the catalytic performance of $\mathrm{Ni} / \mathrm{Al}_{2} \mathrm{O}_{3}$ catalysts in the hydrodechlorination of 1,1,2-trichloroethane," Journal of Molecular Catalysis A: Chemical, vol. 256, no. 1-2, pp. 178-183, 2006.

[40] G. Li, L. Hu, and J. M. Hill, "Comparison of reducibility and stability of alumina-supported $\mathrm{Ni}$ catalysts prepared by impregnation and co-precipitation," Applied Catalysis A: General, vol. 301, no. 1, pp. 16-24, 2006.

[41] K. V. R. Chary, D. Naresh, V. Vishwanathan, M. Sadakave, and W. Ueda, "Vapour phase hydrogenation of phenol over Pd/C catalysts: a relationship between dispersion, metal area and hydrogenation activity," Catalysis Communications, vol. 8, no. 3, pp. 471-477, 2007.

[42] A. B. Gaspar, G. R. dos Santos, R. de Souza Costa, and M. A. P. da Silva, "Hydrogenation of synthetic PYGAS-effects of zirconia on $\mathrm{Pd} / \mathrm{Al}_{2} \mathrm{O}_{3}$," Catalysis Today, vol. 133-135, pp. 400-405, 2008.

[43] D. O. Simone, T. Kennelly, N. L. Brungard, and R. J. Farrauto, "Reversible poisoning of palladium catalysts for methane oxidation," Applied Catalysis, vol. 70, no. 1, pp. 87-100, 1991.

[44] A. B. Gaspar and L. C. Dieguez, "Dispersion stability and methylcyclopentane hydrogenolysis in $\mathrm{Pd} / \mathrm{Al}_{2} \mathrm{O}_{3}$ catalysts," Applied Catalysis A: General, vol. 201, no. 2, pp. 241-251, 2000.

[45] L. Li, Z. H. Zhu, Z. F. Yan, G. Q. Lu, and L. Rintoul, "Catalytic ammonia decomposition over $\mathrm{Ru} /$ carbon catalysts: the importance of the structure of carbon support," Applied $\mathrm{Ca}$ talysis A: General, vol. 320, pp. 166-172, 2007.

[46] A. Guerrero-Ruiz, P. Badenes, and I. Rodríguez-Ramos, "Study of some factors affecting the Ru and Pt dispersions over high surface area graphite-supported catalysts," Applied Catalysis A: General, vol. 173, no. 2, pp. 313-321, 1998. 
[47] M. Nurunnabi, K. Murata, K. Okabe, M. Inaba, and I. Takahara, "Effect of Mn addition on activity and resistance to catalyst deactivation for Fischer-Tropsch synthesis over $\mathrm{Ru} / \mathrm{Al}_{2} \mathrm{O}_{3}$ and $\mathrm{Ru} / \mathrm{SiO}_{2}$ catalysts," Catalysis Communications, vol. 8, no. 10, pp. 1531-1537, 2007.

[48] V. Ragaini, R. Carli, C. L. Bianchi, D. Lorenzetti, and G. Vergani, "Fischer-Tropsch synthesis on alumina-supported ruthenium catalysts I. Influence of $\mathrm{K}$ and $\mathrm{Cl}$ modifiers," Applied Catalysis A: General, vol. 139, no. 1-2, pp. 17-29, 1996.

[49] K. Lu and B. Tatarchuk, "Activated chemisorption of hydrogen on supported ruthenium I. Influence of adsorbed chlorine on accurate surface area measurements," Journal of Catalysis, vol. 106, no. 1, pp. 166-175, 1987.

[50] T. Narita, H. Miura, M. Ohira et al., "The effect of reduction temperature on the chemisorptive properties of $\mathrm{Ru} / \mathrm{Al}_{2} \mathrm{O}_{3}$ : effect of chlorine," Applied Catalysis, vol. 32, pp. 185-190, 1987.

[51] T. Narita, H. Miura, K. Sugiyama, T. Matsuda, and R. D. Gourales, "The effect of reduction temperature on the chemisorptive properties of $\mathrm{Ru} / \mathrm{SiO}_{2}$ : effect of chlorine," Journal of Catalysis, vol. 103, no. 2, pp. 492-495, 1987.

[52] C. R. Lederhos, J. M. Badano, M. E. Quiroga, F. ColomaPascual, and P. C. L'Argentière, "Influence of Ni addition to a low-loaded palladium catalyst on the selective hydrogenation of 1-heptyne," Química Nova, vol. 33, no. 4, pp. 816-820, 2010.

[53] M. J. Maccarrone, C. R. Lederhos, G. Torres et al., "Partial hydrogenation of 3-hexyne over low-loaded palladium mono and bimetallic catalysts," Applied Catalysis A: General, vol. 441-442, pp. 90-98, 2012.

[54] NIST X-ray Photoelectron Spectroscopy Database-NIST Standard Reference Database 20 Version 4.1, National Institute of Standards and Technology, Gaithersburg, MD, USA, December 2017, https://srdata.nist.gov/xps/.

[55] M. M. Telkar, J. M. Nadjeri, C. V. Rode, and R. V. Chaudhari, "Role of a co-metal in bimetallic Ni-Pt catalyst for hydrogenation of m-dinitrobenzene to m-phenylenediamine," Applied Catalysis A: General, vol. 295, no. 1, pp. 23-30, 2005.

[56] J. Juan-Juan, M. C. Roman-Martinez, and M. J. Illan-Gomez, "Catalytic activity and characterization of $\mathrm{Ni} / \mathrm{Al}_{2} \mathrm{O}_{3}$ and $\mathrm{NiK} /$ $\mathrm{Al}_{2} \mathrm{O}_{3}$ catalysts for $\mathrm{CO}_{2}$ methane reforming," Applied $\mathrm{Ca}$ talysis A: General, vol. 264, no. 2, pp. 169-174, 2004.

[57] B. W. Hoffer, A. D. van Langeveld, J. P. Janssens, R. L. C. Bonné, C. M. Lok, and J. A. Moulijn, "Stability of highly dispersed $\mathrm{Ni} / \mathrm{AlO}$ catalysts: effects of pretreatment," Journal of Catalysis, vol. 192, no. 2, pp. 432-440, 2000.

[58] E. Heracleous, A. F. Lee, K. Wilson, and A. A. Lemonidou, "Investigation of Ni-based alumina-supported catalysts for the oxidative dehydrogenation of ethane to ethylene: structural characterization and reactivity studies," Journal of $\mathrm{Ca}$ talysis, vol. 231, no. 1, pp. 159-171, 2005.

[59] M. Boudart, "Catalysis by supported metals," Advances in Catalysis, vol. 20, pp. 153-166, 1969.

[60] J. A. Pajares, P. Reyes, L. A. Oro, and R. Sariego, "Hydrogenation of 1-hexene by rhodium catalysts," Journal of Molecular Catalysis, vol. 11, no. 2-3, pp. 181-192, 1981.

[61] M. J. Maccarrone, G. Torres, C. Lederhos et al., "Kinetic study of the partial hydrogenation of 1-heptyne over $\mathrm{Ni}$ and $\mathrm{Pd}$ supported on alumina," in Hydrogenation, I. Karamé, Ed., Chapter 7, pp. 159-184, InTech, Rijeka, Croatia, 2012. 


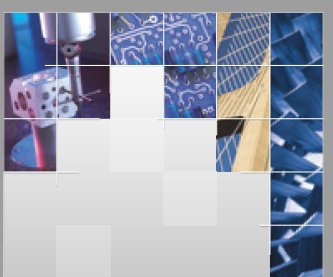

\section{Enfincering}
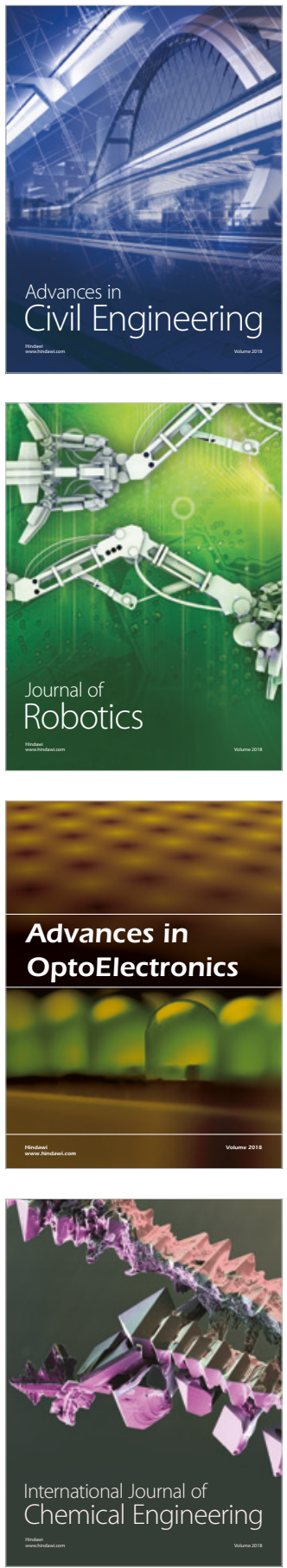

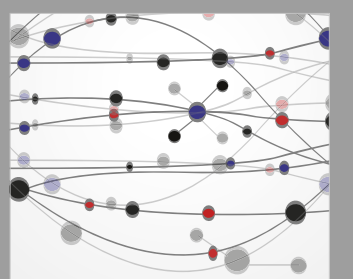

\section{Rotating \\ Machinery}

The Scientific World Journal

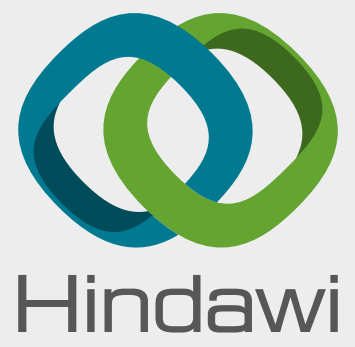

Submit your manuscripts at

www.hindawi.com
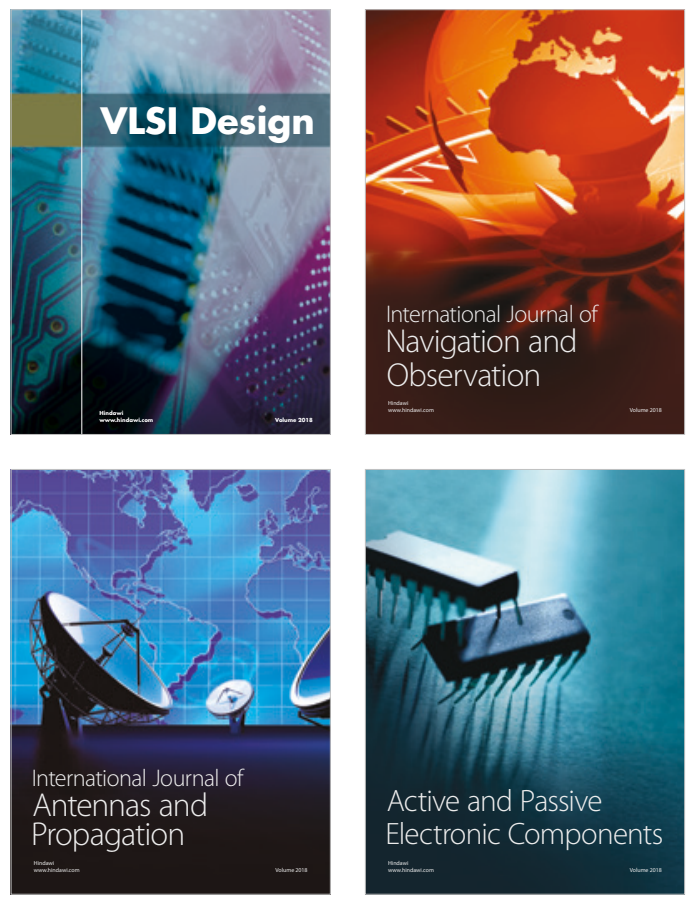
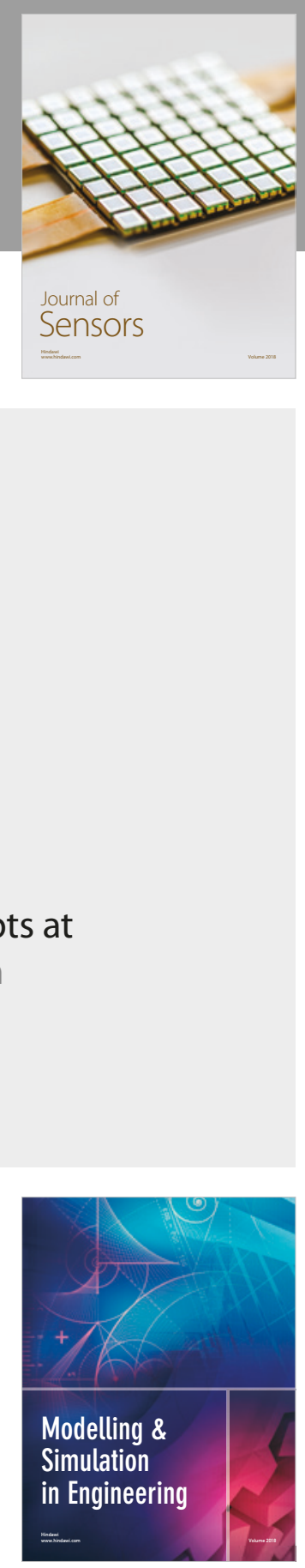

\section{Advances \\ Multimedia}
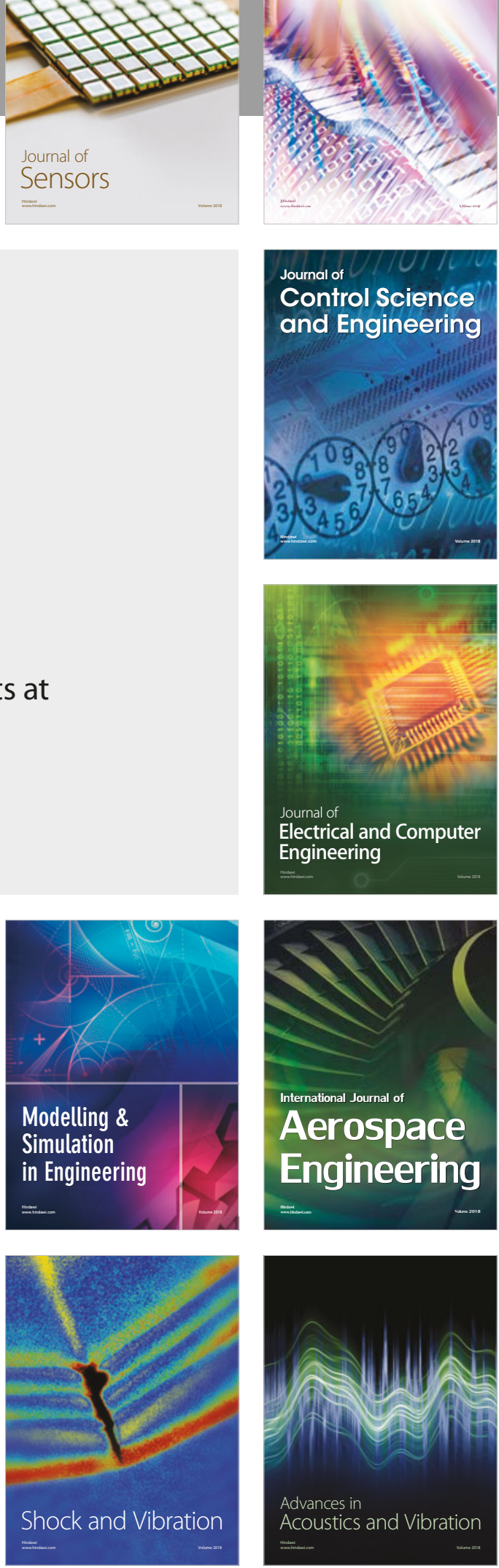